\title{
Pemanfaatan Internet Sebagai Media Pembelajaran Daring Bagi Siswa SD di Tempuran Trimurjo
}

\author{
Erni Mariana ${ }^{1}$, Kusuma Wardany ${ }^{2^{*}}$, Novita $^{3}$ \\ 1, 2, 3, Universitas Nahdlatul Ulama Lampung \\ ${ }^{2}$ kusuma.wardany@ymail.com
}

\begin{abstract}
Abstrak
Kegiatan pengabdian masyarakat ini adalah tentang pemanfaatan internet sebagai media pembelajaran daring bagi siswa SD. Tujuan program ini yaitu untuk membantu anak sekolah di lingkungan sekitar dalam hal belajar, terutama dalam memahami mata pelajaran yang sulit selama pembelajaran daring dari sekolah. Luaran dari program pelatihan ini adalah untuk meningkatkan pengetahuan siswasiswi dalam bidang pengembangan teknologi informasi pendidikan dalam mata pelajaran yang menggunakan membelajaran secara online atau daring. Penggunaan media pembelajaran yang di implementasikan menggunakan smartphone ini dapat meningkatan kompetensi siswa.
\end{abstract}

Kata Kunci: teknologi, media belajar, pembelajaran daring

\section{Pendahuluan}

Pada biasanya warga sekitarnya sangat menunjang aktivitas belajar mengajar teruji banyaknya anak-anak sekolah, dimana menampilkan warga tersebut menunjang pembelajaran. Dengan terbentuknya wabah pandemi Covid-19 dimana siswa diwajibkan belajar dari rumah didampingi orang tua, terdapat pula yang orang tuanya berikan kebebasaan kepada anaknya buat bermain hendak 3 namun tidak menutup mungkin orang tua pula membagikan penafsiran kepada anaknya mengapa wajib belajar dari rumah, Hingga kami berupaya buat membagikan pengajaran sembari bermain secara online. Penelitian Dewi (2020) menunjukkan bahwa adanya pendemi covid-19 sangat berdampak pada implementasi pembelajaran daring di sekolah. Kurangnya fasilitas handphonedan kuota internet menjadi salah satu penyebab terhambatnya pembelajaran secara online.Dimana dikala ini Pembelajaran serta Kebudayaan yang mewajibkan sekolah buat memberlakukan pendidikan dari rumah. Pendidik merasa kaget sebab wajib mengganti sistem, silabus serta proses belajar secara kilat. Siswa terbata- bata sebab menemukan tumpukan tugas sepanjang belajar dari rumah. Sedangkan, orang tua murid merasa stress kala mendampingi proses pendidikan dengan tugas- tugas, di samping wajib memikirkan keberlangsungan hidup serta pekerjaan tiap- tiap di tengah krisis.

Pertumbuhan ilmu pengetahuan serta teknologi yang jadi karakteristik abad- 21 dan milenium ketiga membagikan pengaruh terhadap segala tatanan kehidupan secara global. Pertumbuhan teknologi data dikala ini sudah menjalar serta merambah tiap dimensi aspek kehidupan manusia. Teknolgi data dikala ini memainkan kedudukan yang 
besar didalam aktivitas bisnis, pergantian sturktur organisasi, serta mannajemen organisasi. Dilain pihak, teknologi data pula membagikan peranan yang besar dalam pengembangan keilmuan serta jadi fasilitas utama dalam sesuatu institusi akademik. Merambah abad 21 ataupun milenium ketiga hendak terjalin perpindahan paradigma ataupun cara berfikir dalam mengalami bermacam fenomena tercantum pola pikir yang berkaitan dengan pembelajaran.

Dalam proses pendidikan, seseorang guru mempunyai peranan berarti demi tercapainya aktivitas pendidikan di sekolah. Guru jadi ujung tombak terciptanya proses pendidikan. Walaupun guru memiliki kecerdasan tanpa didukung dengan media pendidikan yang baik hingga proses pendidikan itu hendak menjenuhkan dan kurang menarik atensi siswa. Pertumbuhan IPTEK terhadap proses pendidikan merupakan diperkayanya sumber belajar serta media pendidikan. Media PC dimanfaatkan dalam pendidikan sebab membagikan keuntungan- keuntungan yang tidak dipunyai oleh media pendidikan yang lain ialah keahlian PC buat berhubungan secara individu dengan mahasiswa. Sebelumnya kajian berkaitan dengan peranan teknologi dalam pendidikan seperti ini sudah banyak dilakukan salah satunya oleh Andri Rogantina Meri (2017), yang menjelaskan bahwa teknologi sangat berperan dalam meningkatkan mutu pendidikan. selain itu peran teknologi dapat meningkatkan efektifitas dan efisiensi proses belajar mengajar sehingga dapat mempermudah dalam mencapai tujuan pendidikan.

Dalam pendidikan butuh terdapatnya media pendidikan ialah internet. Dengan terdapatnya media tersebut tiap siswa sanggup menggunakan internet cocok dengan kebutuhan pembelajaran. Di samping itu pemanfaatan internet selaku media pembelajaran sangat memudahkan siswa dalam dalam mengakses suatu data pengetahuan, mengirim tugas-tugas sekolah melalui email, serta sebagainnya. Tidak hanya siswa, guru pula bisa memudahkan dalam mengantarkan pendidikan. Pemanfaatan media internet sangat berarti untuk terlaksananya pendidikan yang baik. Dalam pelaksanaannya pembelajaran daring tentunya tidak dapat terlepas dari peran teknologi. Teknologi dapat mempermudah segala kebutuhan dalam proses belajar mengajar. Sejalan dengan pendapat Tounderetal (dalam Selwyn, 2011) yang mengatakan bahwa tenologi digital dalam lembaga pendidikan sebagai sarana pendukung dalam pembelajaran, baik sebagai sarana dalam mengakses informasi sumber belajar ataupun sebagai sarana penunjang kegiatan belajar dan berkaitan dengan tugas. Teknologi internet pada hakikatnya merupakan perkembangan teknologi informasi dan komunikasi. Dengan adanya internet yang memiliki keunggulan interaktif, dapat juga sebagai media massa dan interpersonal, sumber informasi atau gudangnya informasi dari seluruh penjuru dunia, dan sangat mungkin dimanfaatkan sebagai sumber pembelajaran. Dengan internet, bisa memilih dan mengunduh worksheet serta kegiatan yang sesuai dengan level peserta didik dan disesuaikan dengan topik kegiatan yang diperlukan (Rachmijati, 2018). Hasil penilaian pembelajaran lewat WA sepanjang separuh semester, pembelajaran daring lewat WA dikira menjenuhkan oleh partisipan peserta didik sebab tidak di dukung oleh fitur-fitur yang lengkap. Partisipan peserta didik kurang memotivasi dalam semangat belajar daring atau online sebab mereka cuma sebatas bisa membaca pesan serta memakai voicenote, dialog antar sahabat pula terasa kurang maksimal dampaknya cuma sebagian partisipan didik saja yang aktif di kala pendidikan daring berlangsung. 
Pembelajaran yang dirancang secara baik dan kreatif dengan memanfaatkan multimedia, dalam batas-batas tertentu akan dapat memperbesar kemungkinan siswa untuk belajar lebih banyak mencamkan apa yang dipelajarinya, lebih baik, dan meningkatkan penampilan (performance) siswa dalam rangka meningkatkan ketercapaian kompetensi (Miftah, 2013). Media sebagai bagian integral pembelajaran, komponen ini perlu mendapatkan perhatian para guru.Pembelajaran daring yang dilaksanakan ini mempunyai berbagai kekurangan diantaranya adalah keterbatasan penguasaan teknologi informasi oleh guru dan siswa, sarana dan prasarana yang kurang memadai, akses internet yang terbatas, kurangnya penyediaan anggaran atau biaya yang digunakan untuk pembelajaran daring ini (Syah, 2020). Selain itu, pembelajaran daring juga menuntut orang tua untuk selalu mendampingi anaknya selama belajar dari rumah.

Upaya peningkatan mutu pembelajaran pasti tidak terlepas dari bermacam faktor yang menunjang, antara lain: sistem pembelajaran, media pendidikan, fasilitas dan prasarana, guru, tata cara dan kedudukan aktif siswa serta orang tua. Dari sebagian hal tersebut, salah satu aspek terutama dalam kenaikan mutu pembelajaran yaitu aspek Guru, sebab guru lah yang terletak di dalam ruang kelas serta sangat memahami kekurangan serta kelebihan dari para siswanya.

Kaitannya dengan pemanfaatan dan penggunaan internet maka guru sebagai pengelola kelas harus bisa mengarahkan siswa dalam mengakses internet, karena dalam pengaksesan internet segi positif dan negatif. Sehingga dari penjelasan diatas, agar pembelajaran bisa disesuaikan dengan lajunya perkembangan teknologi maka diperlukan inovasi agar KBM berjalan dengan baik,lancar,efektif dan menyenangkan.

Suprihatin, et al (2020) mengemukakan bahwa peran orang tua siswa sangat penting dalam pembelajaran daring karena orang tua yang harus membimbing dan mengawasi anak-anak saat belajar di rumah. Namun, tidak sedikit orang tua yang merasa kesulitan saat mendampingi anaknya saat pembelajaran daring tersebut. Banyak orang tua yang tidak menguasai cara penggunaan teknologi informasi yang digunakan sebagai media dalam pembelajaran daring. Selain itu, kendala yang dihadapi para orang tua adalah adanya pengeluaran kuota internet yang bertambah karena pembelajaran daring ini memerlukan jaringan internet dan kuota. Kendala selanjutnya yang dirasakan orang tua yaitu mereka tidak dapat meluangkan waktu yang banyak untuk mendampingi anaknya belajar, karena orang tua sendiri mempunyai kesibukannya masing-masing, apalagi bagi orang tua yang harus berkerja di luar rumah karena bergantung pada penghasilan harian. Selain itu, kendala yang dihadapi saat mendampingi anak dalam pembelajaran daring yaitu orang tua merasa kewalahan karena tidak memahami materi pelajaran sekolah anaknya, apalagi bagi orang tuanya yang tidak mempunyai latar belakang pendidikan yang tinggi.

Tujuan dilakukannya program kerja ini yaitu untuk membantu anak sekolah dilingkungan sekitar dalam hal belajar, terutama dalam memahami mata pelajaran yang sulit selama pembelajaran daring dari sekolah. Sebagai upaya dalam mewujudkan salah satu Tri Dharma Perguruan Tinggi, melalui program ini diharapka dapat memberikan kontribusinya dalam bidang pendidikan demi memajukan dan menambah pengetahuan mengenai dunia pendidikan. Selain itu, program ini dapat memberikan ilmu yang baru untuk para mahasiswa dengan bentuk kepeduliannya terhadap masyarakat. Saptomo \& Rimawati (2020) mengemukakan bahwa poada masa new normal ini semua sekolah 
menyiapkan pendidikan dengan sistem e-learning. Sebagian besar para guru sudah mempersiapkan sekenario pembelajaran daring tersebut, tetapi mereka kesuliatan dalam mengemas materi yang akan disajikan secara daring. Para guru juga hanya menggunakan media Sosial (Whatsapp) belum menggunakan media LMS.

\section{Metode Pelaksanaan}

Pelaksanaan kegiatan pengabdian dilakukan dengan melalui rangkaian pelatihan yang dilakukan secara berkala dalam jangka waktu 2 Minggu pelaksanaan pengabdian. Secara sistematis pelatihan dilakukan sesuai dengan urutan, sehingga pelaksanan pengabdian dapat mencapai target utama. Meningkatkan pengetahuan orang siswa-siswi dalam bidang pengembangan teknologi informasi pendidikan dalam mata pelajaran yang menggunakan pembelajaran secara online atau daring, Meningkatan kompetensi siswasiswi menggunakan media pembelajaran yang dapat diimplementasikan pada penggunaan smartphone. Kelompok siswa-siswa SD disekitar lingkungan di Tempuran 12 B Trimurjo dalam ini merupakan mitra tunggal yang pada pelaksanaan akan di stimulus agar dapat mengikuti kegiatan secara aktif dan terampil.Akhir dari pelaksanaan pengabdian adalah mengukur dan menilai capaian dan tingkat keterlaksanaan kegiatan yang telah dilakukan. Muara dari pengabdian ini adalah peningkatan Kelompok siswasiswa SD, oleh karena itu pengukuran keberhasilan dari kegiatan pengabdian ini adalah ketika siswa-siswi telah mampu menggunakan media pembelajaran yang dapat diimplementasikan pada penggunaan smartphone.

Aktivitas pengabdian masyarakat ini berupa dengan pendekatan sosial. Pendekatan sosial dicoba dengan mengaitkan kelompok target selaku subyek aktivitas, tidak cuma hanya objek aktivitas. Pendekatan sosial dengan mengaitkan kelompok target dalam proses persiapan buat meningkatkan pemahaman kalau mereka mempunyai permasalahan semacam yang diformulasikan serta butuh dicoba pemecahan permasalahan. Pendekatan sosial ini pula dibutuhkan buat berikan jaminan kelancaran penerapan aktivitas.

Langkah-langkah aktivitas yang ditempuh dilaksanakan dalam 4 sesi selaku berikut ini:

1. Sesi 1 ialah identifikasi kasus Pada sesi ini kelompok pelaksana mengadakan observasi dan wawancara. Observasi serta wawancara ini dilaksanakan dengan berdiskusi dengan siswa dan para guru.

2. Sesi 2 ialah pengolahan data serta penentuan pemecahan masalah Pada sesi ini kelompok pelaksana mencerna seluruh data baik berbentuk masukan hasil survei serta wawancara. Kajian teoretik serta empiris dikumpulkan terpaut dengan usaha membagikan pemecahan terhadap masalah- masalah yang sudah teridentifikasi. Ada pula pemecahan yang lekas butuh dicoba merupakan lewat pemakaian internet selaku optimalisasi instructional media.

3. Sesi 3 ialah penataan materi pelatihan Pada sesi ini kelompok pelaksana mulai menyusun materi kepada para partisipan serta mencari rujukan yang cocok.

4. Sesi 4 ialah aktivitas pelaksanaan. Pada sesi ini merupakan aktivitas sangat berarti, ialah pelaksaan aktivitas. Aktivitas ini dilaksanakan di salah satu rumah siswa atau ruangan kosong yang bisa digunakan sebagai tempat pendampingan dalam 
pembelajaran online atau daring, pada bertepatan pada 19 Maret 2021 dari mulai jam 08.00 sampai 14.00. Aktivitas pemberian materi dan pendampingan dilaksanakan, pemberian materi berlangsung dekat 30 menit serta dilanjutkan dengan tahap tanya jawab dan langsung ke praktekytairu menggunakan smartphone.

Waktu pelaksanaan adalah hari Rabu, tanggal 19 Maret 2021, pukul 08.00 sampai dengan selesai. Lokasi pengabdian kepada masyarakat berlokasi di Tempuran 12 B Kecamatan Trimurjo. Sasarannya adalah para Kelompok siswa-siswa SD disekitar lingkungan di Tempuran 12 B Trimurjo yang berjumlah 12 orang.

\section{Hasil dan Pembahasan}

Kegiatan pengabdian kepada masyarakat ini, dilaksanakan disekitar lingkungan di Tempuran 12 B Trimurjo, dimana yang menjadi sasaranya itu kelompok siswa-siswa SD. Pada kegiatan pengabdian kali ini, aktivitas yang dilakukan berupa pendekatan sosial. Pendekatan sosial dicoba dengan mengaitkan kelompok target selaku subyek aktivitas, tidak hanya objek aktivitas. Pendekatan sosial dengan mengaitkan kelompok target dalam proses persiapan buat meningkatkan pemahaman kalau mereka mempunyai permasalahan semacam yang diformulasikan serta butuh dicoba pemecahan permasalahan. Pendekatan sosial ini pula dibutuhkan untukmemberikan jaminan kelancaran penerapan aktivitas. Adapun langkah- langkah aktivitas yang ditempuh dilaksanakan dalam 4 sesi sebagai berikut ini:

\section{Sesi I}

Pada sesi I ini aktivitas yang dilakukan yaitu pelaksanaan mengadakan observasi dan wawancara. Pada sesi ini dilakukan pendekatan dengan cara berdiskusi kepada siswa dan para guru. Hasil diskusi ini menunjukkan bahwa adanya antusias yang besar dari semua siswa dan para guru tentang "Pemanfaatan Internet Sebagai Media Pembelajaran Daring Bagi Siswa SD". Pada sesi ini juga dapat diketahui apa saja yang menjadi masalah salama proses pembelajaran daring, baik masalah bagi siswa ataupun masalah yang dihadapi para guru.

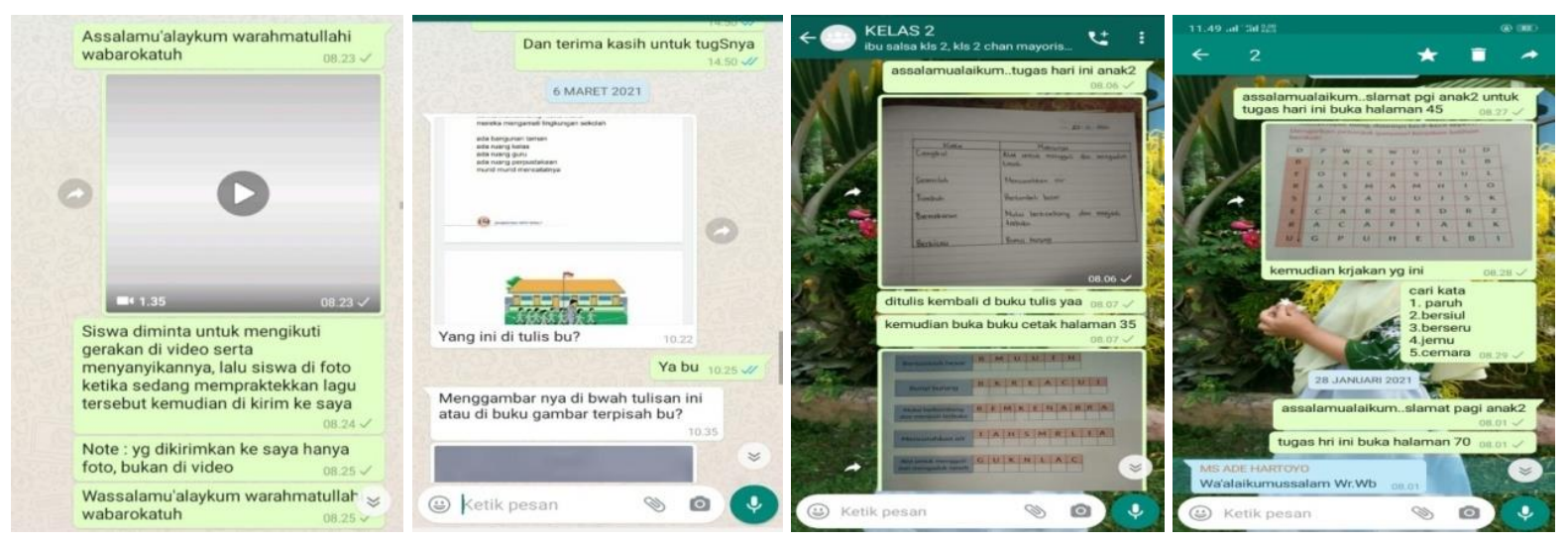

Gambar 1. Berdiskusi dan pengiriman tugas ke siswa melalui whattshap 


\section{Sesi II}

Sesike II ialah pengolahan data serta penentuan pemecahan masalah. Pada sesi ini kelompok pelaksana mencerna seluruh data baik berbentuk masukan hasil survei serta wawancara. Kajian teoretik serta empiris dikumpulkan terpaut dengan usaha membagikan pemecahan terhadap masalah- masalah yang sudah teridentifikasi. Ada pula pemecahan yang lekas butuh dicoba merupakan lewat pemakaian internet selaku optimalisasi instructional media.

\section{Sesi III}

Pada sesi ini kelompok pelaksana mulai menyusun materi kepada para partisipan sertamencari rujukan yang cocok. Sesi ini dilakukan agar apa yang akan disampaikan saat pelaksanaan pendampingan dan pembelajaran sesuai dengan kebutuhan siswa. Tahap ini juga merupakan pemecahan masalah yang sudah di ketahui secara langsung pada saat kegiatan diskusi dengan siswa dan wali guru.

\section{Sesi IV}

Pertemuan pada sesi 4 ini pemateri memberikan penjelasan mengenai materi yang sudah ditentukan. Aktivitas pemberian materi berlangsung sekitar 30 menit serta dilanjutkan dengan tahap tanya jawab dan langsung ke praktek yaitu menggunakan smartphone. Selama proses kegiatan inti dilakukan pula pendampingan secara langsung kepada para peserta, dengan harapan masing-masing dari peserta dapat memahami serta mepraktekkannya secara langsung. Sehingga pemateri dapat mengetahui dan memantau secara langsung apakah materi yang disampaikan sudah dapat dipahami atau belum.

Seluruh peserta yang mengikuti kegiatan pengabdian ini sangat antusias dalam melaksanakan berbagai intruksi yang diberikan oleh pemateri. Saat kegiatan pelatihan berlangsung juga diberikan waktu untuk Tanya jawab. Dari hasil pengamatan selama kegiatan berlangsung peserta terlihat sangat tertarik dan peserta merasa sangat perlu dengan adanya kegiatan pelatihan yang telah diberikan, karena melalui pelatihan ini selain menambah pengetahuan peserta juga mendapat pengembangan media pembelajaran berbasis pemanfaatan internet.

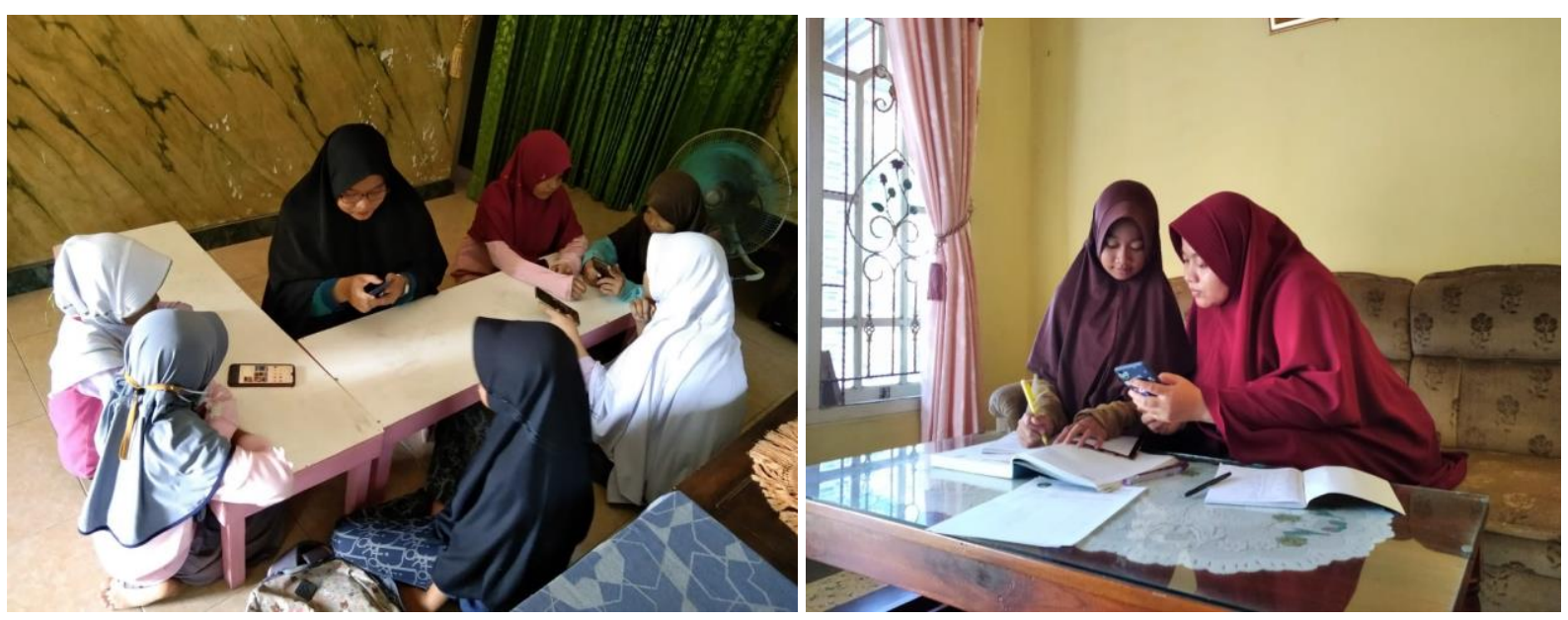

Gambar 2. Antusias siswa dalam belajar menggunakan media internet 
Selama kegiatan berlangsung para peserta tidak hanya menunjukkan antusias yang tinggi, melainkan seluruh peserta juga mengikuti kegiatan pengabdian ini secara konsisten dari awal hingga akhir kegiatan. Karena melalui kegiatan ini para siswa dapat meningkatkan pengetahuan bidang teknologi dalam penggunaan smartphone yang berbasis internet. Dalam hal perlu adanya kegiatan lanjutan yang memberikan materi pelatihan kepada para guru wali. Pelatihan dapat berupa bagamaina cara guru merancang pembelajaran berbasis mobile dengan menggunakan system berbasis internet secara lebih luas. Sehingga dapat membantu meningkatkan kualitas guru dalam memanfaatkan teknologi informasi dengan lebih baik.

Terdapat hambatan dalam pembelajaran daring yaitu datang dari peserta didik, semangat belajar peserta didik selama proses pembelajaran daring menurun dibandingkan ketika pembelajaran tatap muka langsung. Penurunan motivasi belajar peserta didik dipengaruhi oleh beberapa faktor, salah satunya yaitu kondisi selama pembelajaran daring yang mewajibkan peserta didik untuk belajar di rumahnya masingmasing, sehingga memaksa mereka untuk mempelajari serta memahami materi pelajaran secara mandiri (Cahyani Adetya, dkk, 2020). Ketersampaian materi ajar juga menjadi rendah dikarenakan peserta didik hanya mengerjakan tugas saja tanpa diberi penjelasan oleh guru. Meskipun peserta didik tetap diberi tugas untuk membaca materi tetapi menurut guru kedua sekolah tetap belum mampu untuk meningkatkan pemahaman peserta didik akan materi ajar. Kondisi tersebut disadari oleh guru-guru kedua sekolah (Syahroni et al., 2020).

Teknologi dapat menggantikan guru. Teknologi pendidikan dapat menjadi bernilai ketika seorang pendidik dapat menggunakannya dengan baik, kreatif, inovatif serta dapat mempermudah siswanya dalam memahami pembelajaran yang disampaikan. dikatakan teknologi dapat menggantikan guru yaitu dari penggunaan media pembelajaran yang diperbolehkan, misal internet (Hanifah Salsabila et al., 2020).

Teknologi dalam dunia pendidikan tentunya menggunakan media pembelajran untuk mendukung aktivitas pembelajaran secara daring. Menurut Asyhar (2012) ada empat jenis media pembelajaran, yaitu: a) Media visual, yaitu jenis media yang digunakan hanya mengandalkan indera penglihatan semata-mata dari peserta didik, misalnya: media visual non proyeksi (benda realita, model protetif, dan grafis), dan media proyeksi (powerpoint, paint dan auto cad), b) Media audio, yaitu jenis media yang digunakan dalam proses pembelajaran dengan hanya mengandalkan indera pendengaran siswa, misalnya: radio, pita kaset suara, dan piringan hitam, c) Media audio-visual, yaitu jenis media yang digunakan dalam kegiatan pembelajaran dengan melibatkan pendengaran dan penglihatan sekaligus dalam satu proses atau kegiatan, misalnya: video kaset dan film bingkai, d) Multimedia, yaitu media yang melibatkan beberapa jenis media dan peralatan secra terintegrasi dalam suatu proses atau kegiatan pembelajaran, misalnya: TV dan powerpoint. Penelitian (Sriyono, 2018) menyimpulkan bahwa Media pembelajaran menggunakan internet sangat berguna dalam membantu proses belajar mengajar. Komunikasi antara guru dan siswa berlangsung baik dan informasi yang disampaikan guru dapat diterima siswa, guru perlu menggunakan media pembelajaran. 


\section{Kesimpulan}

Berdasarkan uraian pelaksanaan kegiatan pengabdian ini, maka dapat ditarik kesimpulan bahwa Sistem pendidikan dilaksanakan lewat fitur personal computer (Komputer) ataupun laptop yang tersambung dengan koneksi jaringan internet. Pendidik bisa melaksanakan pendidikan bersama di waktu yang sama memakai tim di media sosial semacam WhatsApp (WA), telegram, instagram, aplikasi zoom maupun media yang lain selaku media pendidikan. Dengan demikian, pendidik bisa membenarkan partisipan didik mengikuti pendidikan dalam waktu bertepatan, walaupun di tempat yang berbeda. Pendidik juga bisa berikan tugas terukur cocok dengan tujuan modul yang di informasikan kepada partisipan didik. Penguasaan kompetensi siswa dalam mengelola pembelajaran daring di lakukan dengan strategi (a) penyamaan persepsi kebutuhan pembelajaran daring,(b) pemilihan LMS yang sesuai dengan karakter Sekolah, Guru, dan Peserta Didik, (c) pendampingan intensif dalam praktek langsung pelaksanaan pembelajaran daring.(d) pembuatan materi pembelajaran dalam bentuk media interaktif dapat dilakukan dengan memanfaatkan media sosial yang familiar dengan peserta didik atau siswa, (e) penggunaan media LMS serta media sosial memberikan gairah dalam aktifitas, (f) mengajar guru serta kegiatan peserta didik atau siswa.

\section{Ucapan Terimakasih}

\section{Referensi}

Andri, R. M. (2017). Peran Dan Fungsi Teknologi Dalam Peningkatan Kualitas

Pembelajaran. Jurnal Ilmiah Research Sains, 3(1), 122-29.

http://www.jurnalmudiraindure.com/wp-content/uploads/2017/04/PERAN-

DAN-FUNGSI-TEKNOLOGI-DALAM-PENINGKATAN-KUALITASPEMBELAJARAN.pdf.

Asyhar, R. (2012). Kreatif Mengembangkan Media Pembelajaran. Jakarta: Referensi Jakarta.

Cahyani, A., Listiana, I. D., \& Larasati, S. P. D. (2020). Motivasi Belajar Siswa SMA pada

Pembelajaran Daring di Masa Pandemi Covid-19. IQ (Ilmu Al-qur'an): Jurnal

Pendidikan Islam, 3(01), 123-140. https://doi.org/10.37542/iq.v3i01.57

Dewi, W. A. F. (2020). Dampak COVID-19 terhadap Implementasi Pembelajaran Daring di Sekolah Dasar. Edukatif: Jurnal Ilmu Pendidikan, 2(1), 55-61.

https://doi.org/10.31004/edukatif.v2i1.89

Hanifah Salsabila, U., Irna Sari, L., Haibati Lathif, K., Puji Lestari, A., \& Ayuning, A. (2020).

Peran Teknologi Dalam Pembelajaran Di Masa Pandemi Covid-19. Al-

Mutharahah: Jurnal Penelitian Dan Kajian Sosial Keagamaan, 17(2), 188-198.

https://doi.org/10.46781/al-mutharahah.v17i2.138

Miftah, M. (2013). Fungsi, dan peran media pembelajaran sebagai upaya peningkatan kemampuan belajar siswa. Jurnal kwangsan, 1(2), 95.

Rachmijati, C. (2018). Penggunaan Internet Sebagai Optimalisasi Media Pembelajaran Bahasa Inggris (Program Pengabdian Pada Masyarakat Di Desa Margaluyu Kecamatan Cipendeuy). Abdimas Siliwangi, 1(2), 61.

https://doi.org/10.2246o/as.v1i2p61-74.106 
Saptomo, W. L. Y., \& Rimawati, E. (2020). Path Analisis Technology Acceptance Model pada Penerapan Blended Learning. Jurnal Sains dan Informatika, 6(2). https://jsi.politala.ac.id/index.php//SI/article/view/235

Selwyn, N. (2011). Education and Technology: Key Issues and Debates. India: Replika Press Pvt Ltd.

Syah, R. H. (2020). Dampak Covid-19 pada Pendidikan di Indonesia: Sekolah, Keterampilan, dan Proses Pembelajaran. SALAM: Jurnal Sosial Dan Budaya Syar-I, 7(5). https://doi.org/10.15408/sjsbs.v7i5.15314

Sriyono, S. (2018). Internet Sebagai Media Pembelajaran. Prosiding Seminar Nasional Pendidikan KALUNI, 1(November), 994-1001. https://doi.org/10.30998/prossnp.v1io.29

Suprihatin, A., Ananda, T. A., Mahsa, N., Damayanti, W., Alfiyah, G., Nurulita, M. F., \& Arifin, R. (2020). Efektivitas pendampingan belajar anak dalam mengatasi kesulitan orang tua saat pembelajaran daring di masa pandemi di desa kebulusan, kabupaten kebumen. 1-6.

Syahroni, M., Dianastiti, F. E., \& Firmadani, F. (2020). Pelatihan Media Pembelajaran Berbasis Teknologi Informasi untuk Meningkatkan Keterampilan Guru dalam Pembelajaran Jarak Jauh. International Journal Of Community Service Learning, 4(3), 171-172. 